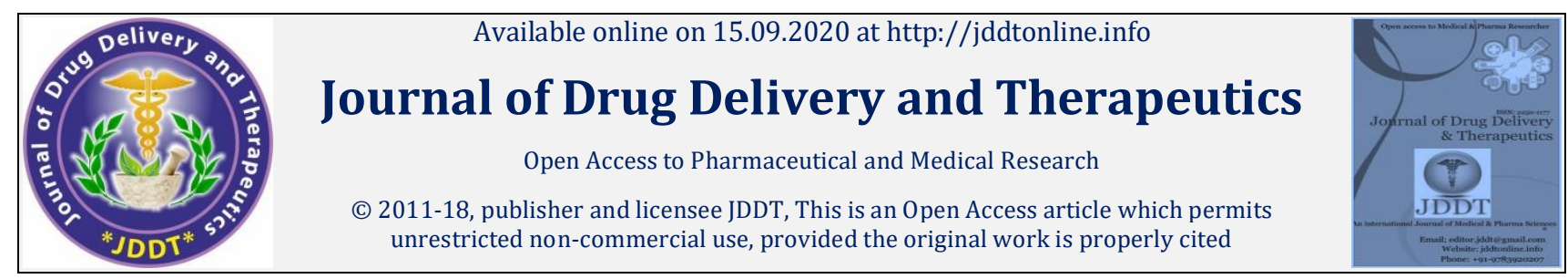

Open@Access

Research Article

\title{
Qualitative Analysis of Phytocompounds of Liagora divaricata and Trematocarpus flabellatus
}

\author{
Dias Valera ${ }^{1 *}$, Uqueio Mauro² ${ }^{2}$ Nhaca Amós ${ }^{3}$, Salência Helena ${ }^{4}$ \\ ${ }^{1}$ Department of Biological Sciences, Eduardo Mondlane University, Maputo, Mozambique \\ 2 Ministry of Sea, Inland Waters and Fisheries, Quelimane, Mozambique \\ ${ }^{3}$ School of Marine and Coastal Sciences, Eduardo Mondlane University, Quelimane, Mozambique (BSc student) \\ ${ }^{4}$ Ministry of Sea, Inland Waters and Fisheries, Maputo, Mozambique
}

\begin{abstract}
Introduction: Phytocompounds are a powerful chemical group obtained from natural resources that exhibit a range of biological activities. Objective: This study explored the phytocompounds constituents of two species of Rhodophyta, Liagora divaricata and Trematocarpus flabellatus in order to give a preliminary view of qualitative diversity of potentially bioactive compounds. Methods: Approximately $200 \mathrm{~g}$ of each species were hand-picked at in Chongoene, Mozambique, during a low spring tide. Voucher specimens were identified and stored at the LMU herbarium in the Department of Biological Science, University of Eduardo Mondlane. Samples were cleaned and dried at $50^{\circ} \mathrm{C}$ for 72 hours before grounding using an electric mixer. Powdered samples were extracted with methanol solvent. Phytocompounds samples were analysed using the GC-MS and identified based in NIST mass spectral library. Results: A total of 42 phytocompounds were identified. The common identities from both seaweeds species include Cholesterol, Desmosterol, Heptadecane, Hexadecanoic acid methyl ester, n-Hexadecanoic acid, Neophytadiene and Phytol. Conclusion: Due to the relevance of these phytocompounds in different industries such as pharmacy, nutrition, agriculture and cosmetic, the identified seaweeds might be good candidates for further research in terms of isolating and validating their activity. Particular attention should be given to Neophytadiene as it is a strong bioactive compound, and can be used for several applications.
\end{abstract}

Keywords: Phytocompounds, Liagora divaricata, Trematocarpus flabellatus, Neophytadiene

Article Info: Received 08 August 2020; Review Completed 17 August 2020; Accepted 24 August 2020; Available online 15 Sep 2020

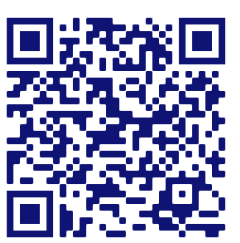

Cite this article as:

Dias V, Uqueio M, Nhaca A, Salência H, Qualitative Analysis of Phytocompounds of Liagora divaricata and Trematocarpus flabellatus, Journal of Drug Delivery and Therapeutics. 2020; 10(5):75-81 http://dx.doi.org/10.22270/jddt.v10i5.4355

*Address for Correspondence:

Valera Dias, University Eduardo Mondlane, Department of Biological Sciences, PO Box 257, Maputo, Mozambique.

\section{INTRODUCTION}

Phytocompounds are a chemical group obtained from natural sources (plants, seaweeds and microalgae) that exhibit a range of biological activities $1,2,3$. There has been growing interest in the application of these bioactive compounds in recent years 4,5 , attracting to the investigation of different species. Among the organisms evaluated for novel phytocompounds, a huge effort has been given to marine habitants 6,7 . Marine organisms habit in complex environments, usually exposed to extreme conditions of temperature, salinity and pressure. They, therefore, produce diverse secondary metabolites that cannot be found elsewhere ${ }^{6}$.

Seaweeds or macroalgae are one of the richest marine sources of several types of biologically active metabolites 8,9 , including alkaloids (e.g. Galanthanine), terpenoids (e.g. Phytol), steroids (e.g. Desmosterol), tannins (e.g.
Octoplorethol), PUFAs (e.g. $\alpha$-linolenic acid), etc $10,11,12$. Seaweeds present a wide spectrum of useful biological properties, which include antibacterial, antiviral, antifungal, antitumor, anti-inflammatory, anti-proliferative, anti-cancer antioxidant, analgesic, algicidal, larvicidal and insecticidal activities 13,14. These properties are tools for biotechnological application in different fields such as medicine, cosmetics, food industry, fertilizers and animal feed 15,16,17. A comprehensive review of phytocompound in seaweeds can be found in Tyśkiewicz et at 18 and Rengasamy et al ${ }^{19}$. However, there are still diverse species of seaweeds that have not been characterized ${ }^{10}$.

Despite the broad application of seaweed in different industries worldwide 20,21,22, this resource in underexploited in Mozambique where nearly 300 species of seaweeds have been documented ${ }^{23}$. To the best of our knowledge, there is no scientific information in Mozambique reporting the phytochemical characterization and application of seaweeds 
metabolites. Therefore, the present study aimed to give a preliminary view of phytocompounds from seaweeds in Mozambique. We analysed two species of Rhodophyta (red seaweeds), Liagora divaricata and Trematocarpus flabellatus that occur in Chongoene. Finding of this study may contribute to the development of a new focus on phytocompounds exploitation and bring a solution to the scientific knowledge gaps in Mozambique and the region.

\section{MATERIALS AND METHODS}

\section{Seaweed collection}

Seaweed sampling was carried out in September 2018 at Chongoene, Mozambique, in the intertidal zone, during a low spring tide. Two species of Rhodophyta, L. divaricata and T. flabellatus were sampled. The specimens were identified using field guides for seaweeds 24,25. Approximately $200 \mathrm{~g}$ of seaweed was hand-picked. A knife was used to remove the seaweeds when necessary. The samples were transported to the Eduardo Mondlane University's laboratory in a basket with seawater to prevent drying. In the laboratory, the samples were cleaned to remove epiphytes and necrotic parts. Samples were rinsed with distilled water to remove salts, sand particles and any associated detritus (miscellaneous) before voucher identifications and storage at the LMU herbarium at the Department of Biological Science, Eduardo Mondlane University. Thereafter, the samples were dried at $50^{\circ} \mathrm{C}$ for 72 hours and were ground in an electric mixer. The powdered samples were weighed and stored in a cool place until further analyses.

\section{Preparation of seaweed extracts}

An amount of $10 \mathrm{~g}$ of each powered sample of seaweeds was transferred into test tubes, treated with Methanol until the powder was fully immersed before overnight incubation. Samples were filtered through a Whatman paper along with Sodium sulphate, which was wet with absolute alcohol. Filtrates were concentrated to $1 \mathrm{ml}$ by bubbling nitrogen gas into the solution.

\section{Identification of phytocompounds using GC-MS}

The analyses of phytochemical compounds were performed according the method described by Abirami and Rajendran 26 , with minor modifications. The extract contains both polar and non-polar components of the material, and $2 \mu \mathrm{l}$ sample of the solution was employed in GC-MS for analysis of different compounds. The GC-MS analysis was carried out using an Agilent 7820A GC System Gas Chromatography equipped and coupled with a mass detector Turbo mass gold, column 5MS, $30 \mathrm{~m}$ (length) $250 \mu \mathrm{m}$ (inner diameter) $0.25 \mu \mathrm{m}$ (film). The instrument was set to an initial temperature of $110^{\circ} \mathrm{C}$ and was maintained at this temperature for 2 minutes. At the end of this period, the oven temperature was raised to $280^{\circ} \mathrm{C}$, at the rate of $5^{\circ} \mathrm{C} / \mathrm{min}$ for a constant of 9 minutes. Injection port temperature was ensured as $250^{\circ} \mathrm{C}$ and Helium flow rate as $1 \mathrm{ml} / \mathrm{min}$.

The ionization voltage was $70 \mathrm{eV}$. The samples were injected in split mode as 10:1. Mass spectral scan range was set at 45$450(\mathrm{~m} / \mathrm{z})$. Interpretation of Mass-Spectrum GC-MS was conducted using the database of National Institute Standard and Technology (NIST) 2016 with more than 62,000 patterns. The spectrum of the unknown components was compared with the spectrum of known components stored in the NIST library. The name, molecular weight and structure of the components of the test materials were ascertained. The compounds in GC-MS analysis were identified based on the comparison of the retention time and mass spectra with the references present in the NIST mass spectral library. The compounds identified in this study were limited to the volatile and volatilizable compounds, which must be capable to retain in the column used. Additionally, the components responsible for the observed peaks were included in the library database.

\section{RESULTS AND DISCUSSION}

GC-MS is highly sensitive equipment and one of the most precise in identifying various compounds in extracts from different solvents 27 . In this study, GC-MS enabled the identification of 42 phytocompounds from the methanolic extracts of the red seaweed L. divaricata, 32 phytocompounds (Table 1) and T. flabellatus, 17 phytocompounds (Table 2). From the phytocompounds identified, seven were common to both extracts, namely: Cholesterol, Desmosterol (both sterols), Heptadecane (Alkane), Hexadecanoic acid methyl ester, n-Hexadecanoic acid (both fatty acid), Neophytadiene and Phytol (both terpenes). The relevance of these phytocompounds is discussed in this study.

Sterols obtained from seaweeds can be used in fields such as pharmacy, nutrition, and cosmetics 27. Indeed, diet containing sterol may reduce the risk of heart disease 29 . These compounds are also associated with antiinflammatory, antibacterial, anti-fungicidal, anti-ulcerative and anti-tumoral effects ${ }^{30}$. Similar to the results of this study, Cholesterol has been identified in several other seaweeds studies 31,32,33. Desmosterol is another sterol found in different species of seaweeds ${ }^{34}$, such as Porphyra sp. and Laminaria $s p .{ }^{34}$.

A range of fatty acid can be found in seaweeds 35,29 . Some of them, such as polyunsaturated fatty acid, are considered essential for humans and animals, and help to prevent the growth of atherosclerotic plaque, reduce blood clotting, blood pressure and improve immune functions 36,29 . In their study, Manilal et al 37 reported that fatty acids from seaweeds possessed proprieties that can be used as ecofriendly anti-fouling. Additionally, fatty acids from seaweeds are a rich substitute for PUFAs that can be used in food formulations 38 . The fatty acids that were identified in both seaweeds analysed in this study - Hexadecanoic acid methyl ester and Hexadecane - were also registered in green seaweeds, Ulva lactucaand Ulva fasciata ${ }^{39}$. Both compounds showed anti-cancer properties in a study conducted in Dictyota bartayresiana (brown seaweed), and they were suggested to be an alternative to synthetic drugs available in the market 40 .

The last group of seaweeds that occur in both species analysed in this study, belong to terpenes. Terpenes are the major class of secondary metabolites with a range of roles in mediating antagonistic and beneficial interaction 41. However, most of them demonstrate qualities of toxins and/or repellents. Indeed, among seaweed phytocompounds, terpenes have merged as the principal chemical defence against grazing by herbivores 42 . Some terpenes from plants show that they are important in resistance to diseases caused by fungi and bacteria. Nevertheless, the functionality and application of many terpenes have not yet been explored 43 .

In this study, the terpenes, Neophytadiene and Phytol, were present in methanolic extracts of the two species analysed. Both phytocompounds were detected in several plants and some microalgae ${ }^{44}$. According to Wei et al ${ }^{41}$, red seaweeds are rich in terpenes. Phytol is a common terpene found in plants and seaweeds and is a precursor for vitamins $\mathrm{E}$ and $\mathrm{K}$ 45. Additionally, Phytol has antibacterial activities against Staphylococcous aureus and antifungal activities against Ganoderma boninense ${ }^{46}$. Similar to Phytol, Neophytadiene is 
an acyclic diterpene. Bhardwaj et al ${ }^{47}$ studied the seaweed Turbinaria ornata and found that Neophytadiene has potential use in inflammatory disorder. Additionally, several studies reported that phytocompounds have strong antibacterial, antifungal, antipyretic, antioxidant, analgesic and vermifugic qualities 48.49 .

Among the phytocompounds identified in this study, Neophytadiene has been reported as a very strong bioactive phytocompound. Therefore, its total ion chromatogram and GC-MS spectrum from both species analysed (L. divaricata and T. flabellatus) are presented as supplementary information, in this study. Further quantitative analysis and additional assays, might elucidate the biological activities of Neophytadiene, in $L$. divaricata and $T$. flabellatus. Nevertheless, the present results are useful bases for the posterior investigation to evaluate these species of seaweeds as potential sources of bioactive compounds.

Table 1: Phytocompounds identified from the methanolic extract of the seaweed L. divaricata, by GC-MS. The phytocompounds highlighted are the ones that were found in methanolic extracts of both seaweeds species analysed in this study.

\begin{tabular}{|c|c|c|c|c|}
\hline & Name & DB Formula & RT & Hits (DB) \\
\hline 1 & .alpha.-Terpineol & $\mathrm{C}_{10} \mathrm{H}_{18} \mathrm{O}$ & 4.779 & 10 \\
\hline 2 & 1,2-15,16-Diepoxyhexadecane & $\mathrm{C}_{16} \mathrm{H}_{30} \mathrm{O}_{2}$ & 23.266 & 9 \\
\hline 3 & 1-Heptadecene & $\mathrm{C}_{17} \mathrm{H}_{34}$ & 25.009 & 10 \\
\hline 4 & 1-Octanol, 2-butyl- & $\mathrm{C}_{12} \mathrm{H}_{26} \mathrm{O}$ & 13.236 & 10 \\
\hline 5 & 2-Pentadecanone, 6,10,14-trimethyl- & $\mathrm{C}_{18} \mathrm{H}_{36} \mathrm{O}$ & 18.479 & 1 \\
\hline 6 & 2-Piperidinone, N-[4-bromo-n-butyl]- & $\mathrm{C}_{9} \mathrm{H}_{16} \mathrm{BrNO}$ & 28.37 & 1 \\
\hline 7 & 3,7,11,15-Tetramethyl-2-hexadecen-1-ol & $\mathrm{C}_{20} \mathrm{H}_{40} \mathrm{O}$ & 19.22 & 10 \\
\hline 8 & 3-Eicosene, (E)- & $\mathrm{C}_{20} \mathrm{H}_{4} \mathrm{O}$ & 21.368 & 10 \\
\hline 9 & 4-tert-Butylcyclohexyl acetate & $\mathrm{C}_{12} \mathrm{H}_{22} \mathrm{O}_{2}$ & 8.229 & 1 \\
\hline 10 & 7-Hexadecenoic acid, methyl ester, (Z)- & $\mathrm{C}_{17} \mathrm{H}_{32} \mathrm{O}_{2}$ & 19.672 & 8 \\
\hline 11 & 7-Tetradecene & $\mathrm{C}_{14} \mathrm{H}_{28}$ & 8.762 & 10 \\
\hline 12 & 9-Octadecenoic acid (Z)-, methyl ester & $\mathrm{C}_{19} \mathrm{H}_{36} \mathrm{O}_{2}$ & 23.482 & 10 \\
\hline 13 & $\begin{array}{l}\text { Benzenepropanoic acid, 3,5-bis(1,1- } \\
\text { dimethylethyl)-4-hydroxy-, methyl ester }\end{array}$ & $\mathrm{C}_{18} \mathrm{H}_{28} \mathrm{O}_{3}$ & 20.458 & 2 \\
\hline 14 & Cholesterol & $\mathrm{C}_{27} \mathrm{H}_{46} \mathrm{O}$ & 39.276 & 9 \\
\hline 15 & Cyclododecane & $\mathrm{C}_{12} \mathrm{H}_{24}$ & 8.593 & 10 \\
\hline 16 & Desmosterol & $\mathrm{C}_{27} \mathrm{H}_{44} \mathrm{O}$ & 40.062 & 2 \\
\hline 17 & Dodecanal & $\mathrm{C}_{12} \mathrm{H}_{24} \mathrm{O}$ & 19.152 & 10 \\
\hline 18 & Dodecanoic acid, methyl ester & $\mathrm{C}_{13} \mathrm{H}_{26} \mathrm{O}_{2}$ & 11.663 & 1 \\
\hline 19 & E-15-Heptadecenal & $\mathrm{C}_{17} \mathrm{H}_{32} \mathrm{O}$ & 17.393 & 10 \\
\hline 20 & Heptadecane & $\mathrm{C}_{17} \mathrm{H}_{36}$ & 15.431 & 10 \\
\hline 21 & Hexadecanoic acid, methyl ester & $\mathrm{C}_{17} \mathrm{H}_{34} \mathrm{O}_{2}$ & 20.082 & 10 \\
\hline 22 & Hexadecen-1-ol, trans-9- & $\mathrm{C}_{16} \mathrm{H}_{32} \mathrm{O}$ & 13.084 & 10 \\
\hline 23 & Methyl stearate & $\mathrm{C}_{19} \mathrm{H}_{38} \mathrm{O}_{2}$ & 23.841 & 6 \\
\hline 24 & Methyl tetradecanoate & $\mathrm{C}_{15} \mathrm{H}_{30} \mathrm{O}_{2}$ & 15.997 & 8 \\
\hline 25 & Neophytadiene & $\mathrm{C}_{20} \mathrm{H}_{38}$ & 18.361 & 10 \\
\hline 26 & n-Hexadecanoic acid & $\mathrm{C}_{16} \mathrm{H}_{32} \mathrm{O}_{2}$ & 20.738 & 10 \\
\hline 27 & Octan-2-one, 3,6-dimethyl- & $\mathrm{C}_{10} \mathrm{H}_{20} \mathrm{O}$ & 4.588 & 3 \\
\hline 28 & Phthalic acid, butyl undecyl ester & $\mathrm{C}_{23} \mathrm{H}_{36} \mathrm{O}_{4}$ & 18.978 & 1 \\
\hline 29 & Phytol & $\mathrm{C}_{20} \mathrm{H}_{40} \mathrm{O}$ & 23.609 & 10 \\
\hline 30 & $\begin{array}{l}\text { Tricyclo[4.2.1.1(2,5)]dec-3-en-9-ol, acetate, } \\
\text { stereoisomer }\end{array}$ & $\mathrm{C}_{12} \mathrm{H}_{16} \mathrm{O}_{2}$ & 9.426 & 1 \\
\hline 31 & Undec-10-ynoic acid, dodecyl ester & $\mathrm{C}_{23} \mathrm{H}_{42} \mathrm{O}_{2}$ & 23.03 & 10 \\
\hline 32 & Z,Z-2,5-Pentadecadien-1-ol & $\mathrm{C}_{15} \mathrm{H}_{28} \mathrm{O}$ & 6.669 & 1 \\
\hline
\end{tabular}


Table 2: Phytocompounds identified from the methanolic extract of the seaweed T. flabellatus, GC-MS. The phytocompounds highlighted are the ones that were found in methanolic extracts of both seaweeds species analysed in this study.

\begin{tabular}{llccc}
\hline & \multicolumn{1}{c}{ Name } & DB Formula & RT & Hits (DB) \\
\hline 1 & 17-Octadecynoic acid & $\mathrm{C}_{18} \mathrm{H}_{32} \mathrm{O}_{2}$ & 18.86 & 10 \\
2 & 1-Heptatriacotanol & $\mathrm{C}_{37} \mathrm{H}_{76} \mathrm{O}$ & 32.21 & 1 \\
3 & Cholest-5-en-3-ol, 24-propylidene-, (3.beta.)- & $\mathrm{C}_{30} \mathrm{H}_{50} \mathrm{O}$ & 44.156 & 4 \\
$\mathbf{4}$ & Cholesterol & $\mathbf{C}_{27} \mathrm{H}_{46} \mathbf{O}$ & $\mathbf{3 9 . 2 7 7}$ & $\mathbf{1 0}$ \\
5 & cis-13-Eicosenoic acid & $\mathrm{C}_{20} \mathrm{H}_{38} \mathrm{O}_{2}$ & 20.458 & 6 \\
$\mathbf{6}$ & Desmosterol & $\mathbf{C}_{27} \mathbf{H}_{44} \mathbf{O}$ & $\mathbf{4 0 . 1 2 6}$ & $\mathbf{7}$ \\
7 & E,E,Z-1,3,12-Nonadecatriene-5,14-diol & $\mathrm{C}_{19} \mathrm{H}_{34} \mathrm{O}_{2}$ & 36.316 & 1 \\
$\mathbf{8}$ & Heptadecane & $\mathbf{C}_{\mathbf{1 7}} \mathbf{H}_{36}$ & $\mathbf{1 5 . 4 2 6}$ & $\mathbf{1 0}$ \\
$\mathbf{9}$ & Hexadecanoic acid, methyl ester & $\mathbf{C}_{\mathbf{1 7}} \mathrm{H}_{34} \mathbf{O}_{2}$ & $\mathbf{2 0 . 0 8 6}$ & $\mathbf{1 0}$ \\
$\mathbf{1 0}$ & Neophytadiene & $\mathbf{C}_{20} \mathrm{H}_{38}$ & $\mathbf{1 8 . 3 6 5}$ & $\mathbf{1 0}$ \\
$\mathbf{1 1}$ & n-Hexadecanoic acid & $\mathbf{C}_{\mathbf{1 6}} \mathrm{H}_{32} \mathrm{O}_{2}$ & $\mathbf{2 1 . 3 7 2}$ & $\mathbf{1 0}$ \\
12 & Oleic Acid & $\mathrm{C}_{18} \mathrm{H}_{34} \mathrm{O}_{2}$ & 24.209 & 10 \\
$\mathbf{1 3}$ & Phytol & $\mathbf{C}_{20} \mathrm{H}_{40} \mathbf{O}$ & $\mathbf{2 3 . 6 2 1}$ & $\mathbf{1 0}$ \\
14 & Phytol, acetate & $\mathrm{C}_{22} \mathrm{H}_{42} \mathrm{O}_{2}$ & 19.219 & 10 \\
15 & Tetradecanoic acid & $\mathrm{C}_{14} \mathrm{H}_{28} \mathrm{O}_{2}$ & 16.729 & 13.079 \\
16 & Z-10-Tetradecen-1-ol acetate & $\mathrm{C}_{16} \mathrm{H}_{30} \mathrm{O}_{2}$ & 17.393 & 10
\end{tabular}

\section{CONCLUSION}

GC-MS analysis allowed the identification of 42 phytocompounds from methanolic extracts of the red seaweed L. divaricate and T. flabellatus. Diverse groups of secondary metabolites were found within the phytocompounds, such as sterols (Cholesterol and Desmosterol), fatty acids (Hexadecanoic acid methyl ester and n-Hexadecanoic acid), and terpenes (Neophytadiene and Phytol). Due to their relevance in different industries such as pharmacy, nutrition, agriculture and cosmetic, these types of seaweed are good candidates for further research in terms of isolating and validating the phytocompounds identified in this study. Particular attention should be given to Neophytadiene as this is a strong bioactive compound with several applications. To the best of our knowledge, this is the first time that secondary metabolites from red seaweed types L. divaricata and T. flabellatus have been evaluated in the region. The results provide new insights regarding the importance of these marine resources.

\section{ACKNOWLEDGEMENT}

This work funded by WIO-RISE (Western Indian Ocean Region Initiative in Science and Education), SIDA (Swedish International Development Cooperation Agency) and UEM (University of Eduardo Mondlane). The authors would also like to thank the Department of Biological Science and the Department of Chemistry at UEM for technical support. Our appreciation goes to Ms Monwa Mhlophe and Dr Emmanuel Vellemu for the language assistance.

\section{CONFLICTS OF INTEREST}

The authors declare that there is no conflict of interests regarding the publication of this paper.

\section{REFERENCES}

1. Sharif MK, Zahid A, Shah FH. Role of Food Product Development in Increased Food Consumption and Value Addition. Food Processing for Increased Quality and Consumption; 2018. p. 455-479.

2. Bathaie SZ, Faridi N, Nasimian A, Heidarzadeh H, Tamanoi F. How Phytochemicals Prevent Chemical Carcinogens and/or Suppress Tumor Growth? The Enzymes; 2015. p. 1-42.

3. Diep CS, Baranowski J, Baranowski T. The impact of fruit and vegetable intake on weight management. Managing and Preventing Obesity; 2015; p. 59-78.

4. Biesalski HK, Dragsted LO, Elmadfa I, Grossklaus R, Müller M, Schrenk D, Weber P. Bioactive compounds: Definition and assessment of activity. Nutrition, 2009; 25(11-12) 1202-1205.

5. Guaadaoui A, Benaicha S, Naima E, Bellaoui M, Hamal A. What is a Bioactive Compound? A Combined Definition for a Preliminary Consensus, International Journal of Nutrition and Food Sciences, 2014; 3(3):174-179.

6. Hamed I, Özogul F, Özogul, Y, Regenstein JM. Marine Bioactive Compounds and Their Health Benefits: A Review. Comprehensive Reviews in Food Science and Food Safety, 2015; 14(4):446-465.

7. Salehi B, Sharifi-Rad J, Seca, AML, Pinto DC, Michalak I, Trincone A, Mishra AP, Nigam M, Zam W, Martins N. Current Trends on Seaweeds: Looking at Chemical Composition, Phytopharmacology, and Cosmetic Applications. Molecules, 2019; 24:4182.

8. Abirami RG, Kowsalya. Phytochemical screening, microbial load and antimicrobial activity of underexploited seaweeds. International Research Journal of Microbiology, 2012; 3(10):328-332.

9. Melpha Y, Manchu N, Edwin J. Phytochemical evaluation of two brown seaweeds from Muttom and Rasthacaud coasts of Tamil Nadu, India. Journal of Chemical and Pharmaceutical Research. 2014; 6(10):566-569.

10. Rengasamy KR, Kulkarni MG, Stirk WA, Van SJ. Bioactive Metabolites and Value-Added Products from Marine Macroalgae. Seafood Processing By-Products, 2013; p. 423-454. 
11. Deyab M, Elkatony T, Ward F. Qualitative and Quantitative Analysis of Phytochemical Studies on Brown Seaweed, Dictyota dichotoma, International Journal of Engineering Development and Research, 2016; 4(2):674-678.

12. Azmir J, Zaidul ISM, Rahman MM, Sharif KM, Mohamed A, Sahena F, Omar AK. M. Techniques for extraction of bioactive compounds from plant materials: A review. Journal of Food Engineering, 2013; 117(4):426-436.

13. Perez JM, Falque EM, Dominguez H. Antimicrobial action of compounds from marine seaweed. Mar. Drugs. 2016; 14(3):5238

14. Sridhar S, Kumar JS, Babu S, Mansuya P, Aruna P. Antibacterial Activity and Qualitative Phytochemical Analysis of Selected Seaweeds from Gulf of Mannar Region. 2010; 1(8):23-26.

15. Carvalho L, Pereira L. Review of Marine Algae as Source of Bioactive Metabolites: a Marine Biotechnology Approach. Marine Algae, 2014; 195-227.

16. Achilonu MC, Umesiobi DO. Bioactive phytochemicals: Bioactivity, sources, preparations, and/or modifications via silver tetrafluoroborate mediation. Journal of Chemistry, 2015; p. 1-22.

17. El-DinSM,El-Ahwany AMD,Bioactivity and phytochemical constituents of marine red seaweeds Uania rubens, Corallina mediterranea and Pterocladia capillacea), Journal of Taibah University for Science, 2016; 10(4):471-484.

18. Tyśkiewicz K, Konkol M, Kowalski R. Characterization of bioactive compounds in the biomass of black locust, poplar and willow. Trees, 2019; 33:1235-1263.

19. Rengasamy KR, Mahomoodally MF, Aumeeruddy MZ, Zengin G, Xiao J, Kim DH. Bioactive compounds in seaweeds: An overview of their biological properties and safety. Food and Chemical Toxicology, 2020; (135): 111013.

20. Osman MEH, Aboshady AM, Elshobary ME. Production and characterization of antimicrobial active substance from some macroalgae collected from Abu- Qir bay (Alexandria) Egypt. African Journal of Biotechnology, 2013; 12(49):6847-6858.

21. Shanmugam J, Devi RK, Viswanathan S, Nallamuthu T. Antibacterial and antioxidant activity of red seaweeds from Kilakarai, Rameswaram, Tamilnadu, India. J. Pharm. Biomed. Sci. 2013; 32:1386-1395.

22. Tanniou A, Vandanjon L, Incera M, Serrano-Leon E, Husa V Assessment of the spatial variability of phenolic contents and associated bioactivities in the invasive alga Sargassum muticum sampled along its European range from Norway to Portugal. J. Appl. Phycol, 2014; 26:1215-1230.

23. Bandeira SO. Seaweed resources of Mozambique. In: The Seaweed Resources of the World, Critchley AT \& Ohno M. (Eds), Japan International Cooperation Agency (JICA), 1998; p. 403408

24. De Clercket O, Bolton JJ, Anderson RJ, Coppejans E. Guide to the seaweeds of KwaZulu-Natal, Scripta Botanica Belgica; 2005. 33. i-283.

25. Richmond MD. A A Field Guide to the Seashores of Eastern Africa and the Western Indian Ocean Islands. $3^{\text {rd }}$ ed. Dar es Salaam: SIDA, WIOMSA, 2011.

26. Abirami RG, Kowsalya S. Phytochemical screening, microbial load and antimicrobial activity of underexploited seaweeds. International Research Journal of Microbiology, 2012; 3:328332.

27. Garg K, Shrivastava B, Bhargava A. GC-MS Analysis of Methanol and Ethyl Acetate Extract of fruits of Sphaeranthus indicus, Journal of Drug Delivery and Therapeutics. 2019. 9(2):28-30.

28. Michalak I, Chojnacka, K. Algae as production systems of bioactive compounds. Engineering in Life Sciences, 2015; 15(2):160-176.

29. Matanjun P, Mohamed S, Mustapha NM, Muhammad K. Nutrient content of tropical edible seaweeds, Eucheuma cottonii, Caulerpa lentillifera and Sargassum polycystum. Journal of Applied Phycology, 2008; 21(1):75-80.

30. Plazza M, Santoyo S, Jaime L, García-Blairsy RG, Herrero M, Señoráns FJ, Ibáñez E. Screening for bioactive compounds from algae. Journal of Pharmaceutical and Biomedical Analysis, 2010; 51(2):450-455.

31. Pereira L, Kim S. 2015 Seaweed flora of the European North Atlantic and Mediterranean. In: Spring handbook of marine Biotechnology. (Eds), Springer, 2016; 65 - 178 pp.

32. Kendel M, Couzinet-Mossion A, Viau M, Fleurence J, Barnathan G, Wielgosz-Collin G. Seasonal composition of lipids, fatty acids, and sterols in the edible red alga Grateloupia turuturu. Journal of Applied Phycology, 2012; 25(2):425-432.

33. Sánchez-Machado DI, López-Hernández J, Paseiro-Losada $P$, López-Cervantes J. An HPLC method for the quantification of sterols in edible seaweeds. Biomed. Chromatogr. 2004; 18:183190.

34. Ilias AM, Connor WE, Lin DS, Ahmad MU. Sterol Composition of Some Seaweeds. Fette, Seifen, Anstrichmittel, 1985; 87(9):345346.

35. Herbreteau F, Coiffard LJM, Derrien A, De Roeck-Holtzhauer Y. The Fatty Acid Composition of Five Species of Macroalgae. Botanica Marina, 1997; 40(1-6), 25-28.

36. Khotimchenko SV, Vaskovsky VE, Titlyanova TV. Fatty Acids of Marine Algae from the Pacific Coast of North California. Botanica Marina, 2002; 45(1):17-22.

37. Manilal A, Sujith S, Sabarathnam B, Kiran GS, Selvin J, Shakir C, Lipton AP. Antifouling potentials of seaweeds collected from the southwest coast of India. World Journal of Agricultural Sciences, 2010; 6(3):243-248

38. Kumari P, Kumar M, Reddy CRK, Jha B. Algal lipids, fatty acids and sterols. Functional Ingredients from Algae for Foods and Nutraceuticals, 2013; 87-134.

39. Bharathi D, Boopathy RA. In Silico Studies On Colon Cancer Against Hexadecane, Hexadecanoic Acid Methyl Ester And Quinoline, 1,2-Dihydro-2,2,4-Trimethyl Compounds From Brown Seaweed. International Journal of Research in Pharmaceutical Sciences, 2020; 11(2):1927-1935.

40. Wei G, Jia Q, Chen X. Terpene Biosynthesis in Red Algae Is Catalyzed by Microbial Type But Not Typical Plant Terpene Synthases. Plant Physiol. 2019; 179(2):382-390.

41. Shobier AH, Abdel Ghani SA, Barakat KM. GC/MS spectroscopic approach and antifungal potential of bioactive extracts produced by marine macroalgae. The Egyptian Journal of Aquatic Research, 2016; 42(3):289-299.

42. Fleury BG, Kelecom A, Pereira RC, Teixeira VL. Polyphenols, Terpenes and Sterols in Brazilian Dictyotales and Fucales (Phaeophyta). Botanica Marina, 1994; 37(5):457-462.

43. Gershenzon J, Dudareva N. The function of terpene natural products in the natural world. Nature Chemical Biology, 2007; 3(7):408-414.

44. Abdel-Aal EI, Haroon AM, Mofeed J.Successive solvent extraction and GC-MS analysis for the evaluation of the phytochemical constituents of the filamentous green alga Spirogyra longata, Egyptian Journal of Aquatic Research, 2015; 41(3):233-246.

45. Nandagopalan V, Gritto MJ, Doss A. GC-MS analysis of bioactive components of the methanol extract of Hibiscus tiliaceus Linn Asian Journal of Plant Science and Research, 2015; 5(3):6-10.

46. Aziz S, Jafarah N, Yusof B, Zetty Z. phytol-containing seaweed extracts as control for Ganoderma boninense. Journal of oil palm research, 2019; 31:238-247.

47. Bhardwaj M, Sali VK, Mani S. Neophytadiene from Turbinaria ornata Suppresses LPS-Induced Inflammatory Response in RAW 264.7 Macrophages and Sprague Dawley Rats. Inflammation, 2020; 43:937-950.

48. El Shafay SM, Ali SS, El-Sheekh MM. Antimicrobial activity of some seaweeds species from Red sea, against multidrug resistant bacteria, Egyptian Journal of Aquatic Research National Institute of Oceanography and Fisheries, 2015; 42(1):65-74.

49. Anjali KP, Sangeetha BM, Devi G, Raghunathan R, Dutta S. Bioprospecting of seaweeds (Ulva lactuca and Stoechospermum marginatum): The compound characterization and functional applications in medicine-a comparative study, Journal of Photochemistry \& Photobiology, B: Biology 2019; 111622. 
Supplementary Information

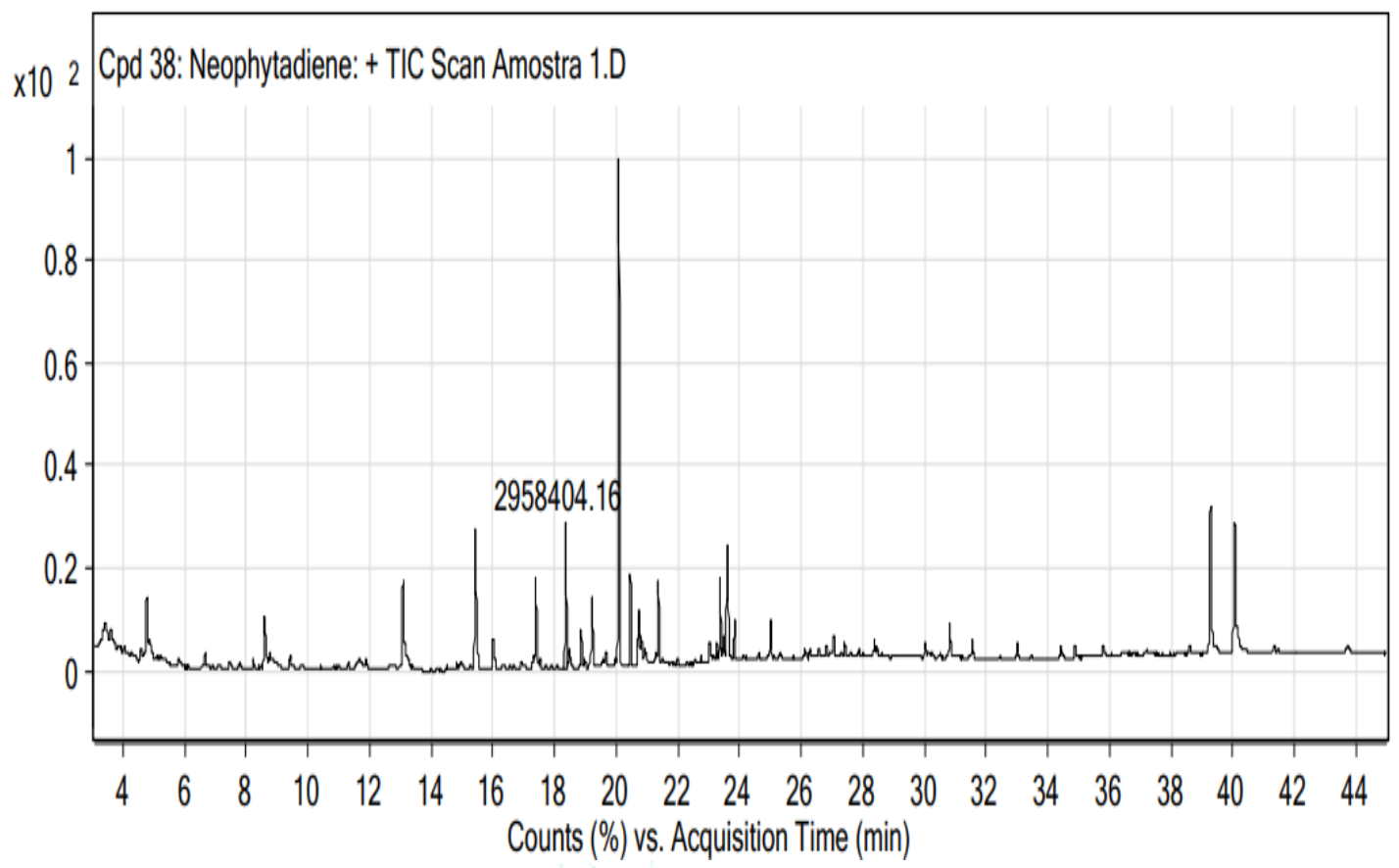

Figure 1: Total ion chromatogram (TIC) of Liagora divaricata methanolic extract highlighting the presence of Neophytadiene phytocompound, analysed in GC-MS.

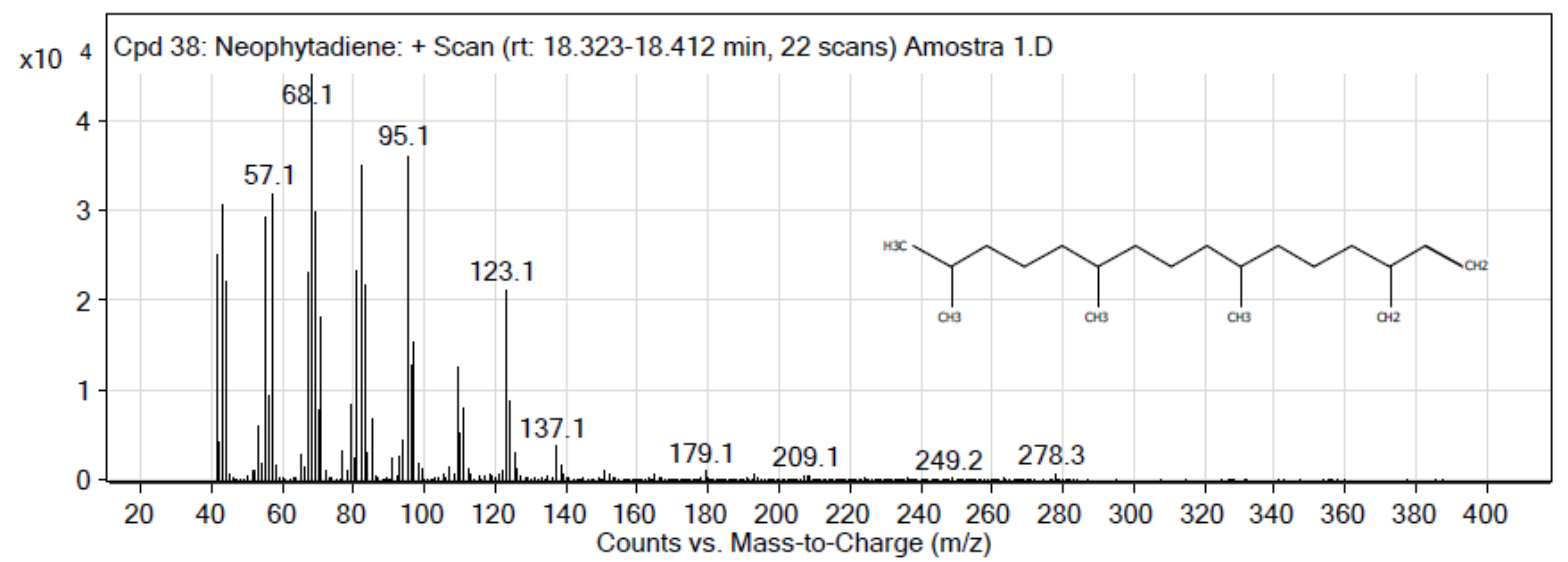

Figure 2: GC-MS spectrum of the phytocompound Neophytadiene from Liagora divaricata methanolic extract.

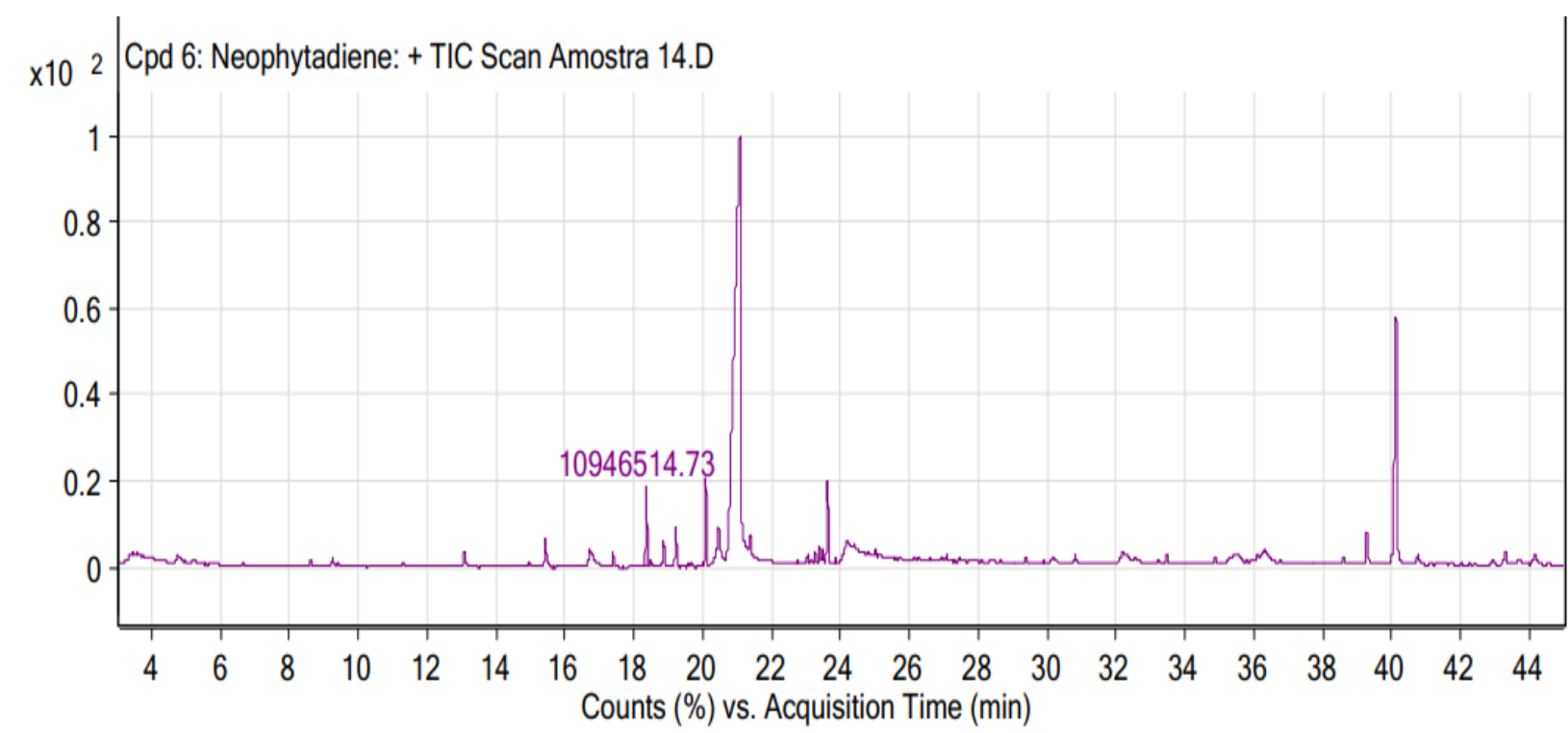

Figure 3: Total ion chromatogram (TIC) of Trematocarpus flabellatus methanolic extract showing Neophytadiene phytocompound, analysed by GC-MS. 
MS Zoomed Spectrum

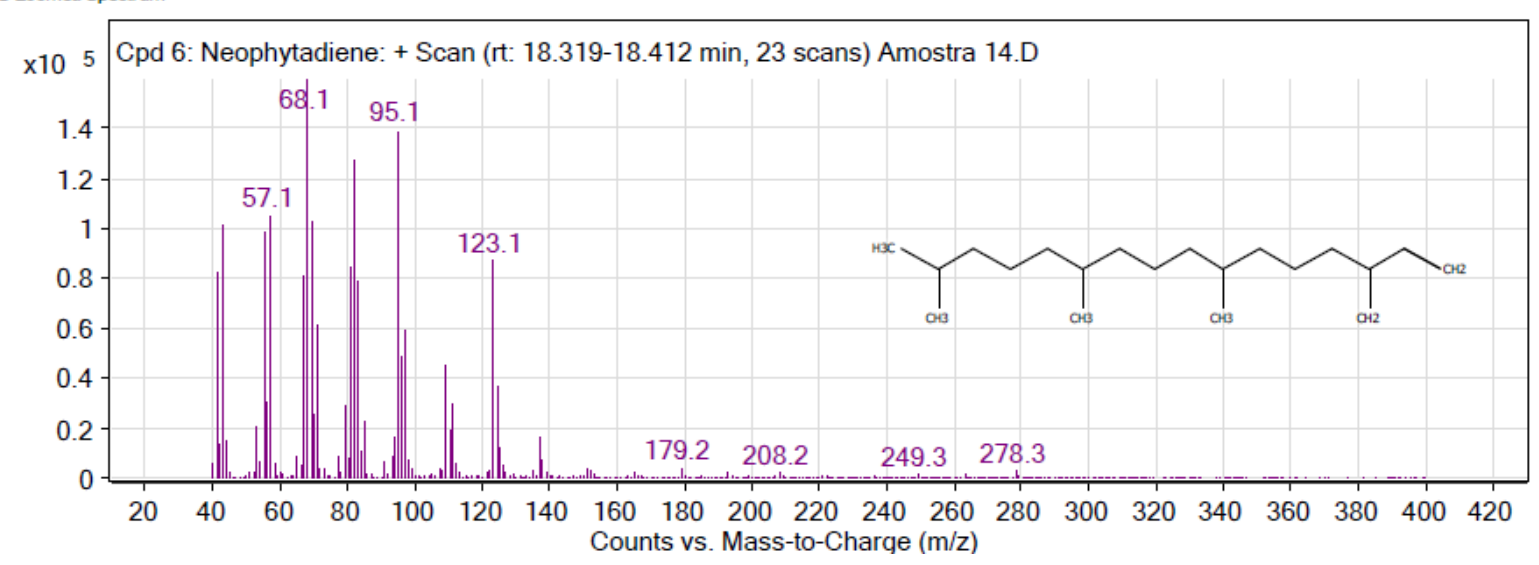

Figure 4: GC-MS spectrum of the phytocompound Neophytadiene from Trematocarpus flabellatus methanolic extract. 